International Journal of

Emerging Multidisciplinary Research

\title{
A Study on the Impact of Knowledge Management on Supplier Orientation in Sustainable Supply chains
}

\author{
Chang Liu ${ }^{1}$ \\ ${ }^{1}$ School of Economics and Management, Taishan University, Tai'an, CO 271000, China
}

\begin{abstract}
Background/Objectives: Over the past few years, sustainable supply chain management (SSCM) has received significant attention and there is a growing expectation to extend sustainability efforts beyond internal operations to suppliers and customers in the supply chain. This paper examines the impact of supplier orientation in supply chain management by using knowledge management as a component of sustainable supply chain management. Methods/Statistical analysis: In this study, a survey was conducted, and analysis was performed using SPSS and PLS 2.0 as statistical tools. Findings: The research results showed that knowledge storage had a certain impact on supplier orientation in sustainable supply chains. Knowledge storage of the enterprises can be regarded as part of the information technology application. Improvements/Applications: There is a need to provide detailed statistics and analysis on the ownership, industry and scale of the enterprises among the research objects, thus providing more or different levels of understanding.
\end{abstract}

\section{Index Terms}

knowledge management, supplier orientation, sustainable supply chain management

\section{Corresponding author : Chang Liu}

1c97123@tsu.edu.cn

- Manuscript received January 21, 2021.

- Revised February 19, 2021; Accepted March 7, 2021.

- Date of publication March 31, 2020.

(C) The Academic Society of Convergence Science Inc.

2546-1583 @ 2018 IJEMR. Personal use is permitted, but republication/redistribution requires IJEMR permission. 


\section{INTRODUCTION}

In consideration of dynamics and instability of the business environment, the enterprises should initiate sustainable supply chain management (SSCM) for higher profitability. According to the concept of Triple Bottom Line (TBL), in addition to economic benefits, the enterprises must take into account social and environmental factors, that is, core enterprises in the supply chains must cause the upstream and downstream enterprises to reach a consensus, not only maximize their own economic benefits, but also pay attention to their environmental performance and social responsibility. It was widely accepted by scholars in dealing with and studying sustainability issues $[1,2]$.

Knowledge is one of the most important competitive resources in organization. Enterprises that can quickly acquire and apply knowledge will gain greater success in market. Therefore, knowledge management was deemed as the key to achieve sustainable competitive advantages in supply chain management. Knowledge management can identify and transform useful information, data and knowledge assets into the companies' sustainable value. Knowledge management in sustainable supply chain management is considered to be a suitable strategy for achieving its competitiveness and sustainability.

Scientific and reasonable positioning of suppliers, good strategic collaboration with suppliers and creation of maximum value for customers have a great impact on the sustainable development of the supply chains. Supplier-oriented knowledge-driven attributes of the core enterprises in the sustainable supply chains were built based on a structural equation model solved by PLS (partial least squares), and their impact on supplier orientation was analyzed.

Supplier orientation in supply chain management was examined by building an enterprise knowledge management evaluation index system. The conclusions have great reference value and significance to enhance the supplier recognition and management efficiency, establish the relationship between knowledge management and supply chains and improve knowledge management and supply chain management.

\section{THEORETICAL BACKGROUND}

\section{A. Knowledge management}

Knowledge management originated in the late 1980s, and was roughly divided into three stages by far. In the early 1990s (Stage I), researchers believed knowledge was data and considered as an object of management from an engineering-oriented perspective (IT-oriented). The task of knowledge management was mainly to store knowledge scattered within and outside the enterprises so that errors occurring in executing business can be avoided whenever possible.

From the mid-1990s to the early 2000s (Stage 2), scholars found that explicit knowledge can only be managed in the knowledge management system. During this period, the viewpoint on knowledge changed dramatically, and knowledge was no longer simply an object to be managed, but a process. In this context "we know more than we can tell" [3], it was difficult to express in words and recognize the importance of implicit knowledge with a higher value.

Creation of people-oriented knowledge became the focus of knowledge management. Since the mid2000s (Stage 3), who had what knowledge, i.e., existence and linkage of meta-knowledge and knowledge-as-contents, had caused the scholars to renew concern about knowledge management activities from a new viewpoint.

Nowadays, knowledge management has become a strategic need for the institutions, organizations and service departments. By managing knowledge capital, the department of enterprise organization has innovated the products, services and business processes, thereby improving its competitiveness.

\section{B. Sustainable supply chain management}

In recent years, many researchers have shifted their focus to sustainable supply chains and closedloop supply chains [4-7]. Seuring and Müller (2008) defined sustainable supply chain management as "the management of materials, information and capital" [8].

Sustainable supply chain management integrated sustainable development goals at all three levels, that is, factors such as economic, environmental and social development were also taken into account, in addition to cooperation between upstream and downstream enterprises in the supply chains. Carter and Rogers (2008) summarized and developed the Triple Bottom Line (TBL) of sustainable supply chain management into risk management, transparency, strategy and culture by sorting out sustainability-related literature [9], and opted to improve the economic, environmental and social performance of the enterprises and the whole supply chains by establishing a cooperative management system in which organizational goals were integrated and achieved in a transparent way.

Hassini et al. (2012) proposed, emphasized that the goal of sustainable supply chain management was to maximize supply chains profits while minimizing environmental impact and maximizing social welfare [10]. Bentahar and Benzidia (2018) redefined sustainable supply chain management 
(SSCM) as "the incorporation of economic, environmental and social dimensions into intra- and inter-organizational flows in an innovative and collaborative way for creating sustainable value" based on the researchers' [11].

Scholars have extensively studied sustainable supply chain management from different perspectives, mainly including the following: first, a collaborative management and innovative research framework for sustainable supply chains was proposed, starting from the whole supply chains; second, a sustainable supplier management evaluation index system was established to screen and evaluate suppliers, starting from performance management and evaluation; third, the optimal solution of economic, social and environmental benefits in supply chain operations was proposed to guide enterprise operations through modeling [12].

Seuring's and Mueller's (2008) supply chain management framework achieved supplier risk \& performance control and supply chain management for sustainable products mainly based on two strategies.

The former focused on supplier management, and mainly achieved sustainable supplier development by improving management quality; the latter focused on product lifecycle, and assessed the product lifecycle by training and developing the production standards. Under this framework, supplier partnership and cooperation were regarded as one of the most important performance indicators [13-16]. The concept and research framework of sustainable supply chain management in this paper were based on the above viewpoints of Seuring and Mueller (2008).

\section{Supplier orientation}

Shin et al. (2000) depicted the supply management orientation as the management effort or concept necessary to "create a business environment in which buyers and suppliers interact in a coordinated manner" [17]. Mentzer et al. (2001) pointed out that "synchronization and integration of intra-enterprise and inter-enterprise operational and strategic capabilities into a unified whole with cooperation as strategic orientation" was one of the core features of the supply chain management concept [18].

An integrated solution was developed by the suppliers in the supply chains to enhance supply chain sustainability, thus achieving a business success [19]. Hollos et al. (2012) defined the strategic orientation of supply chain management as "function integration in strategic planning, understanding and contribution to the strategic goals of the enterprises and predictability of its contribution to these goals"[20].

The professionalism, specialization and cooperation of suppliers were the factors that helped to enhance sustainable supply chain management. Supplier orientation enabled supply chains partners to quickly perceive changes in the supply market, and had a significant impact on increasing an enterprise's market shares and profits [21].

In addition, the enterprises' supplier base determined the overall sustainable development of the enterprises [22]. Close cooperation with suppliers and continuous product innovation were an important driving force for development sustainability [23, 24].

Supplier orientation had a positive impact on the enterprises in the above aspects and provided competitive advantages by promoting sustainable business development.

In order to better understand supply chain management functions and sustainable development capability, there was a need to clarify the impact of supplier orientation on sustainable development in supply chain management. In this paper, supplier orientation referred to an organizational activity of managing supplier relationships to achieve business goals.

\section{HYPOTHESIS AND EVALUATION MODELING}

\section{A. Knowledge management and sustainable supply chain management}

Many scholars attached importance to and discussed the impact and contribution of knowledge management to the supply chains. Duhon (1998) defined knowledge management as an integrated approach to identify, acquire, retrieve and share information in databases, documents, policies, procedures, expertise and experience of knowledge workers [25].

Bloodgood (2009) defined knowledge management as the creation, storage and utilization of conventional programs. This definition has aroused scholars' attentions to the creation, storage, dissemination and application of organizational knowledge in the supply chains [26].

Spekman et al. (2002) argued that supply chain management should gain competitive advantages through effective knowledge management in the process of expanding from individual enterprises to the whole supply chains [27].

Knowledge management was deemed indispensable in developing dynamic core competencies and creating new value by facilitating the application and development of organizational knowledge. Through knowledge management in a sustainable supply chains, knowledge can be 
effectively utilized to provide the best products and services [28]. Knowledge management was deemed as a practical tool in sustainable supply chain management to provide supply chain members with knowledge strategies by which information was shared and converted into action and organizational competitiveness was achieved [29].

Some scholars proved the relationship between knowledge management and supply chain management. Enterprises provided necessary tools to manage a large amount of information and share data generated by supply chain partners and their customers [30].

The task of knowledge management involved not only knowledge management (both explicit and implicit knowledge) from technical aspects through information system [31, 32], but also data management and analysis on quality of knowledge in the supply chains. In terms of supply chain management, the managers should fully understand and monitor the business processes from procurement, logistics, production, retailing and delivery to customers in order to control the whole supply chain operations [33].

Intra-organizational and inter-organizational knowledge management activities were the need for the enterprises to respond to internal and external interests and market changes in sustainable supply chain management.

\section{B. Supplier orientation}

Shin et al. (2000) found that supplier-oriented management can enable the suppliers to actively participate in whole product development, which had a positive impact on supplier quality improvement and long-term stable cooperation with suppliers. Min and Mentzer (2004) divided supply chain management orientation into several dimensions: credibility, benevolence, commitment, norms, compatibility and top management support.

Hollos et al. (2012) identified supplier orientation as business plans adaptive to changes, long-term plans and knowledge; and concluded that the strategic orientation of enterprise procurement and supply management had a positive impact on supplier cooperation and sustainable development. The supplier base determined the sustainability level of the enterprises and the whole supply chains.

The cooperation between the enterprise and the supplier and strategic orientation of the suppliers were closely related to the sustainable development strategy. On this basis, the following hypotheses were proposed:

H1: Knowledge storage has a positive impact on supplier orientation in sustainable supply chain management.
H2: Knowledge transfer has a positive impact on supplier orientation in sustainable supply chain management.

The results from SmartPLS2.0 showed that Cronbachs a of knowledge storage, knowledge transfer, knowledge acquisition and supplier orientation was $0.937,0.940,0.931$ and 0.941 respectively. Cronbachs a of all the latent variables was $>0.9$, and the composite reliability far exceeded the critical value of 0.7 , up to 0.845 , indicating that the questionnaires showed good consistency. The results showed that all the variables in this paper had high reliability.

H3: Knowledge acquisition has a positive impact on supplier orientation in sustainable supply chain management.

\section{RESEARCH METHODOLOGY}

\section{A. Research questions}

Part 1 of the questionnaire mainly collects demographic information, that is, gender, age, and occupation of respondents; Part 2 describes supplier orientation in enterprise knowledge management and sustainable supply chain management.

Knowledge management indicators were selected, and a system was established. Shakerian et al., (2016) and Lim et al., (2017) measured knowledge management activities from three dimensions of knowledge storage, knowledge transfer and knowledge acquisition) [34, 35].

Knowledge storage, knowledge transfer and knowledge acquisition involved 5, 8 and 7 questions respectively; the supplier-oriented measurement indicators in the sustainable supply chains were mainly studied and reorganized by Lintukangas (2019) [36], and there were a total of 7 questions. The questionnaires were scored using the 5-point Likert scale (1 strongly agree, 3 uncertain, 5 strongly disagree).

\section{B. Measures}

This paper took the middle and senior managers of the enterprises as the members of the Supply Chain and Cold Chain Association of Tai'an City, Shandong Province as the research object. The survey was conducted through online questionnaire from October 11, 2020 to October 18, 2020.

A total of 180 questionnaires were issued and 152 were recycled, of which 126 were valid, with an effective rate of $82.9 \%$. Middle and senior managers of the enterprises as research objects were familiar with the enterprises and industries, so that the validity and reliability of the questionnaires were guaranteed. 


\section{DATA ANALYSIS AND RESULTS}

\section{A. Data analysis}

The samples were analyzed by SPSS, and the reliability and validity of each indicator were verified using PLS2.0. 41 woman (accounting for 32.5\%) and 85 men (accounting for $67.5 \%$ ) were surveyed. 99 persons were over 35 years old, accounting for $78.6 \%$; 33 persons, accounting for $26.2 \%$, had a high school degree or technical secondary school diploma, accounting for $26.2 \%$. 93 persons had a college degree or above, accounting for $83.8 \%$.

\section{B. Reliability and validity analysis}

The results from Smart PLS2.0 showed that Cronbach's a of knowledge storage, knowledge transfer, knowledge acquisition and supplier orientation was $0.937,0.940,0.931$ and 0.941 respectively.

Cronbach's a of all the latent variables was $>0.9$, and the composite reliability far exceeded the critical value of 0.7 , up to 0.845 , indicating that the questionnaires showed good consistency. The results showed that all the variables in this paper had high reliability.

Table 1. Variable Reliability Test Results

\begin{tabular}{llllc}
\hline \hline & $\begin{array}{l}\text { Average } \\
\text { variance } \\
\text { extracte } \\
\text { d (AVE) }\end{array}$ & $\begin{array}{l}\text { Composite } \\
\text { reliability } \\
\text { (CR) }\end{array}$ & Square & $\begin{array}{r}\text { Rronbachs } \\
\text { Alpha }\end{array}$ \\
\hline $\begin{array}{l}\text { Knowledge } \\
\text { storage }\end{array}$ & 0.799 & 0.952 & 0.937 \\
$\begin{array}{l}\text { Knowledge } \\
\text { transfer }\end{array}$ & 0.705 & 0.950 & 0.940 \\
$\begin{array}{l}\text { Knowledge } \\
\text { acquisition } \\
\text { Supplier } \\
\text { orientation }\end{array}$ & 0.709 & 0.945 & 0.931 \\
\hline
\end{tabular}

The questionnaire and its items were derived from the research results already verified, and were readapted and designed according to the research contents. Therefore, the questionnaire had high content validity. For the test on construction validity, the validity was generally measured from two aspects, namely convergent validity and discriminative validity. The convergent validity of the latent variables can be reflected by AVE, and the statistical results showed that the AVE of the latent variable was greater than 0.7 , indicating that each latent variable presented very high convergent validity. The factor loading of all the observational variables was greater than 0.82 , indicating that the observed variables showed high convergent validity.

\section{Model testing}

This paper tested all the path hypotheses in the research model using structural equations to identify a path in which supplier orientation in sustainable supply chains was affected by knowledge management activities and the extent of the effect. The results are shown in Fig. 1.

The results showed that the hypothesis proposed in this paper was partially supported. All the path coefficients were significant when $\mathrm{p}<0.01$. Research hypotheses $\mathrm{H} 1$ and $\mathrm{H} 3$ were supported. It can be seen from the $\mathrm{R}^{2}$ value that the path coefficients of knowledge storage, knowledge transfer and knowledge acquisition were $0.236,-0.035$ and 0.753 respectively, and the explained variance rate of customer satisfaction was 84.5 .

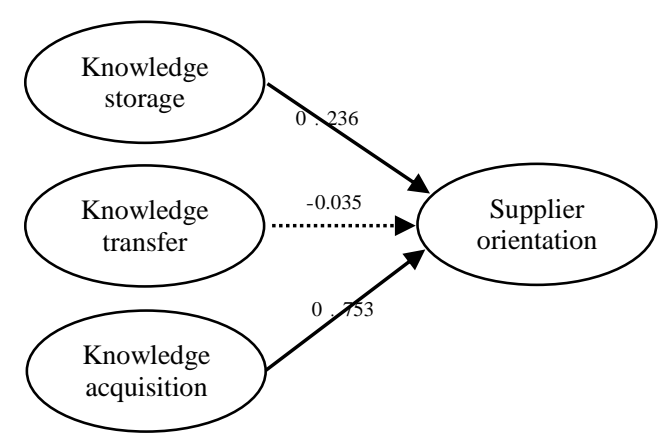

Fig. 1. Model Results

Note: $* \mathrm{p}<0.10 ; * \mathrm{p}<0.05 ; * * * \mathrm{p}<0.01$; NS: insignificant

This showed that knowledge acquisition was an important factor for supplier orientation management during supplier orientation management of sustainable supply chain management.

The T-value of knowledge storage, knowledge transfer, knowledge acquisition and supplier orientation was 14.337, 1.592 and 50.939 respectively, indicating that knowledge storage had a certain impact on supplier orientation in sustainable supply chains; knowledge transfer had an insignificant impact on supplier orientation in sustainable supply chains; the impact of knowledge acquisition on supplier orientation in sustainable supply chains was very significant.

\section{Conclusions}

This paper attempted to obtain an evaluation tool by scientifically validating the dimensionality, reliability and validity of the research model. The model measured the knowledge management activities of the enterprises in three dimensions of knowledge storage, knowledge transfer and knowledge acquisition, determined the relationship 
between attributes for enterprise managers, explored the role of knowledge management in sustainable supply chain management, and provided a conceptual framework for knowledge management in sustainable supply chains.

The research results showed that knowledge storage had a certain impact on supplier orientation in sustainable supply chains. Knowledge storage of the enterprises can be regarded as part of the information technology application.

It mainly helped the enterprises archive and organize scattered data and information. Basic data of these enterprises can not only help the enterprises effectively contact their supply chains partners, but also help the enterprises innovate the products and services, so as to improve business performance and maintain competitiveness.

Knowledge acquisition activities of sustainable supply chains partners were mainly carried out and realized in light of contract documents with supply chains partners, internal structure meetings, social software applications and business processes. As a collaborative knowledge management tool, social software provided a possibility for organization participants to store, transfer, acquire, maintain and share knowledge.

Social software helped to store information and processes related to supply chain partners and cooperation. Enterprises can achieve the goal of knowledge management by learning and sharing internal information.

Especially in the initial stage of supply chains development, knowledge socialization among supply chain partners was more important. Through knowledge acquisition and knowledge storage, knowledge sharing and transfer can eliminate network barriers and contribute to active development of trade relations between the company and its competitors.

It was the first time to incorporate knowledge management into sustainable supply chain management, and there were some limitations. First, the measurement indicators of knowledge management activities were not within the scope of sustainable supply chain knowledge management activities.

Knowledge was a decisive attribute of sustainable supply chain management, and the key success factors of knowledge management adopted by different scholars and small and medium-sized enterprises were also different.

The knowledge management activities in sustainable supply chain management not only included internal knowledge management, knowledge creation and production, but also knowledge resources and knowledge management processes developed or established by supply chain partners during operation. Second, when the sample was selected, only the middle and senior managers of the enterprises among the members of the Supply Chain and Cold Chain Association of Tai'an City, Shandong Province were taken as the research objects during survey, not applicable for other industries.

There is a need to provide detailed statistics and analysis on the ownership, industry and scale of the enterprises among the research objects, thus providing more or different levels of understanding.

\section{REFERENCES}

[1] Ahi, P., Searcy, C. (2013). A comparative literature analysis of definitions for green and sustainable supply chain management. Journal of Cleaner Production, 52(aug.1), 329-341.

[2] Tseng, M.L., Lim, M.K., Wong, W.P. (2015). Sustainable supply chain management: a closed-loop network hierarchical approach. Ind. Manag. Data Syst, 115 (3), 436461.

[3] Polanyi, M. (1962). Tacit knowing: Its Bearing on Some Problems of Philosophy. Reviews of Modern Physics, 34(4), 601-616

[4] Indranil, B., Alok, R., Srivastava, S. K. (2018). Supply chain channel coordination with triple bottom line approach. Transportation Research Part E Logistics \& Transportation Review, 115, 213-226.

[5] Saberi, S. (2018). Sustainable, multiperiod supply chains network model with freight carrier through reduction in pollution stock. Transp. Res. Part E: Logist. Transp. Rev. $118,421-444$

[6] Kannan, D., Mina, H., Nosrati-Abarghooee, S., Khosrojerdi, G. (2020). Sustainable circular supplier selection: A novel hybrid approach. The Science of the Total Environment, 722, 137936.

[7] Am, A., Dk, B., Reh, A., So, A., Ma, C., Ebt, D. . Evaluation of green and sustainable supply chain management using structural equation modelling: a systematic review of the state of the art literature and recommendations for future research. Journal of Cleaner Production, 249

[8] Seuring, S., Müller, M. (2008). Core issues in sustainable supply chain managementea Delphi study. Bus. strategy Environ, 17 (8), 455-466.

[9] Carter, C.R., Rogers, D.S. (2008).A framework of sustainable supply chain management: moving toward new theory. Int. J. Phys. Dist. Logist. Manag. 38 (5), 360-387.

[10] Hassini, E., Surti C., Searcy, C. (2012). A literaturere view and a case study of sustainable supply chains with a focus on metrics, Int. J. Prod. Econ.140(1), 69-82

[11] Bentahar, O., Benzidia, S., Sustainable supply chain management: Trends and challenges. Transp. Res. Part E: Logist. Transp. Rev.2018, 119, 202-204.

[12] Tang Jin huan, Zhao Yi ge, Zhao Li qiang. (2019). Research on the Progress and Trend of Sustainable Supply Chain Management Based on Bibliometrics. Science Technology and Industry. 019(008): 68-77

[13] Akamp, M., Müller, M. (2013). Supplier management in developing countries. Journal of Cleaner Production, 56, 54-62.

[14] Cruz, J. (2013). Modeling the relationship of globalized supply chains and corporate social responsibility. Journal of Cleaner Production, 56, 73-85.

[15] Leppelt, T., Foerstl, K., Reuter, C., Hartmann, E. (2013). Sustainability management beyond organizational boundaries-sustainable supplier relationship management in the chemical industry. Journal of Cleaner Production, 56, 94-102 
[16] Steven, M., Merklein, T. (2013). The influence of strategic airline alliances in passenger transportation on carbon intensity, Journal of Cleaner Production, 56, 112-120.

[17] Shin, H., Collier, D., Wilson, D. (2000). Supply management orientation and supplier/buyer performance. Oper. Manag, 18 (3), 317-333.

[18] Mentzer, J.T., DeWitt, W., Keebler, J.S., Min, S., Nix, N.W., Smith, C.D., Zacharia, Z., (2001). Defining supply chain management. Bus. Logist, 22 (2), 1-25.

[19] Windahl, C., Lakemond, N. (2006). Developing integrated solutions: the importance of relationships within the network. Ind. Mark. Manag, 25 (7), 806-818.

[20] Hollos, D., Blome, C., Foerstl, K. (2012). Does sustainable supplier co-operation affect performance? Examining implications for the triple bottom line. Int. Prod. Res, 50(11), 2968-2986.

[21] Paulraj, A. (2011). Understanding the relationship between internal resources and capabilities, sustainable supply management and organizational sustainability. Supply chains Manag, 47 (1), 19-37.

[22] Grosvold, J., Hoejmose, S., Roehrich, J. (2014). Squaring the circle: management, measurement and performance of sustainability in supply chains. Supply chains Manag.: Int 19 (3), 292-305

[23] Gualandris, J., Golini, R., Kalchschmidt, M. (2014). Do supply management and global sourcing matter for firm sustainability performance? Supply chains Manag.: Int, 19(3), 258-274.

[24] Paulraj, A., Chen, I.J., Blome, C. (2017). Motives and performance outcomes of sustainable supply chain management practices: a multi-theoretical perspective. Journal of Business Ethics, 145(2), 239-258.

[25] Duhon, B. (1998). It's all in our heads. Inform 12 (8), 8-13.

[26] Bloodgood, J.M. (2009). Organisational Routines as Mechanisms for Knowledge Creation, Utilisation, and Storage. In Knowledge Management and Organisational Learning. Springer, New York, USA. ISBN: 9781441900074.

[27] Spekman, R.E., Spear, J., Kamauff, J. (2002). Supply chain competency: learning as a key component. Supply Chain Manag. Int. J. 7 (1), 41-55.

[28] Sambasivan, M., Loke, S.P., Abidin-Mohamed, Z. (2009). Impact of knowledge management in supply chain management: a study in Malaysian manufacturing companies. Knowl. Process Manag. 16 (3), 111-123.

[29] Lindblom, A., Tikkanen, H. (2010). Knowledge creation and business format franchising. Manag. Decis. 48 (2), 179-188.

[30] Dost, M., Badir, Y. F., Ali, Z., Tariq, A. (2016). The impact of intellectual capital on innovation generation and adoption. Journal of Intellectual Capital, 17(4), 654-674.

[31] Gunasekaran, A., Ngaie, E W. T. (2007). Knowledge management in 21 st century manufacturing. International Journal of Production Research, 45(11), 2391-2418

[32] Schoenherr, T., Griffith, D. A., Chandra, A. (2014) Knowledge management in supply chains: the role of explicit and tacit knowledge. Journal of Business Logistics, 35(2), 121-135.

[33] Vural, Altuntas, C. (2015). Sustainable demand chain management: an alternative perspective for sustainability in the supply chain. Procedia - Social and Behavioral Sciences, 207, 262-273.

[34] Shakerian, H., Dehnavi, H. D., Shateri, F. (2016). A framework for the implementation of knowledge management in supply chain management. Procedia-Social and Behavioral Sciences, 230, 176-183.

[35] Lim, M. K., Tseng, M. L., Tan, K. H., Bui, T. D. (2017) Knowledge management in sustainable supply chain management: improving performance through an interpretive structural modelling approach. Journal of Cleaner Production, 162(sep.20), 806-816.

[36] Lintukangas, K., Kahkonen, A. K., Hallikas, J. (2019). The role of supply management innovativeness and supplier orientation in firms' sustainability performance. Journal of Purchasing \& Supply Management, 25(4), 100558.1100558.10. 